\title{
Author Correction: Enhancing droplet deposition through in-situ precipitation
}

\author{
Maher Damak, Md Nasim Hyder \& Kripa K. Varanasi
}

Correction to: Nature Communications https://doi.org/10.1038/ncomms12560, published online 30 August 2016.

The original version of this article included Seyed Reza Mahmoudi, who was from "Department of Mechanical Engineering, Massachusetts Institute of Technology, 77 Massachusetts avenue, Cambridge, 02139, Massachusetts, USA", as the second author in the author list. Subsequently this person stated that his contribution to the work was not sufficient to be included as an author. Consequently, this name has been removed from the author list. In addition, the sentence "M.D., S.R.D, N.H. and K.K.V. conceived the project" in the Author Contributions section has been corrected to "M.D., N.H. and K.K.V. conceived the project". This has been corrected in both the PDF and HTML versions of the article.

Published online: 21 August 2020

\footnotetext{
(c) (i) Open Access This article is licensed under a Creative Commons Attribution 4.0 International License, which permits use, sharing, adaptation, distribution and reproduction in any medium or format, as long as you give appropriate credit to the original author(s) and the source, provide a link to the Creative Commons license, and indicate if changes were made. The images or other third party material in this article are included in the article's Creative Commons license, unless indicated otherwise in a credit line to the material. If material is not included in the article's Creative Commons license and your intended use is not permitted by statutory regulation or exceeds the permitted use, you will need to obtain permission directly from the copyright holder. To view a copy of this license, visit http://creativecommons.org/licenses/by/4.0/.
}

(C) The Author(s) 2020 